\title{
Comparison of the mismatch-specific endonuclease method and denaturing high-performance liquid chromatography for the identification of $H B B$ gene mutations
}

\author{
Chia-Cheng Hung ${ }^{\dagger 1}$, Yi-Ning Su ${ }^{\dagger 2,3}$, Chia-Yun Lin ${ }^{1}$, Yin-Fei Chang ${ }^{3}$, Chien- \\ Hui Chang ${ }^{4}$, Wen-Fang Cheng ${ }^{5}$, Chi-An Chen ${ }^{5}$, Chien-Nan Lee ${ }^{* 5}$ and Win- \\ Li $\operatorname{Lin}^{1}$
}

\begin{abstract}
Address: ${ }^{1}$ Institute of Biomedical Engineering, College of Medicine and College of Engineering, National Taiwan University, Taipei, Taiwan, ${ }^{2}$ Graduate Institute of Clinical Medicine, College of Medicine, National Taiwan University, Taipei, Taiwan, ${ }^{3}$ Department of Medical Genetics, National Taiwan University Hospital, Taipei, Taiwan, ${ }^{4}$ Institute of Molecular Medicine, College of Medicine, National Taiwan University, Taipei, Taiwan and ${ }^{5}$ Department of Obstetrics and Gynecology, National Taiwan University Hospital, Taipei, Taiwan

Email: Chia-Cheng Hung - chiacheng@ntu.edu.tw; Yi-Ning Su - ynsu@ntu.edu.tw; Chia-Yun Lin - R92548018@ntu.edu.tw; YinFei Chang - umber7033@yahoo.com.tw; Chien-Hui Chang - P94448010@ntu.edu.tw; Wen-Fang Cheng - wenfangcheng@yahoo.com; ChiAn Chen - cachen@ntumc.org; Chien-Nan Lee* - leecn@ntu.edu.tw; Win-Li Lin - winli@ntu.edu.tw

* Corresponding author †Equal contributors
\end{abstract}

Published: 12 August 2008

BMC Biotechnology 2008, 8:62 doi:10.1 186/1472-6750-8-62

This article is available from: http://www.biomedcentral.com//472-6750/8/62

(C) 2008 Hung et al; licensee BioMed Central Ltd.

This is an Open Access article distributed under the terms of the Creative Commons Attribution License (http://creativecommons.org/licenses/by/2.0), which permits unrestricted use, distribution, and reproduction in any medium, provided the original work is properly cited.
Received: 17 December 2007

Accepted: 12 August 2008

\begin{abstract}
Background: Beta-thalassemia is a common autosomal recessive hereditary disease in the Meditertanean, Asia and African areas. Over 600 mutations have been described in the beta-globin $(H B B)$, of which more than 200 are associated with a beta-thalassemia phenotype.

Results: We used two highly-specific mutation screening methods, mismatch-specific endonuclease and denaturing high-performance liquid chromatography, to identify mutations in the $H B B$ gene. The sensitivity and specificity of these two methods were compared. We successfully distinguished mutations in the HBB gene by the mismatch-specific endonuclease method without need for further assay. This technique had $100 \%$ sensitivity and specificity for the study sample.

Conclusion: Compared to the DHPLC approach, the mismatch-specific endonuclease method allows mutational screening of a large number of samples because of its speed, sensitivity and adaptability to semi-automated systems. These findings demonstrate the feasibility of using the mismatch-specific endonuclease method as a tool for mutation screening.
\end{abstract}

\section{Background}

Beta-thalassemia is one of the most common genetic diseases in the world. It is an autosomal recessive inherited disease resulting from point mutations, small insertions, or deletions in the beta-globin $(H B B)$ gene [1]. Over 600 mutations have been described in the HBB gene, of which more than 200 are associated with a beta-thalassemia phenotype $[2,3]$. The wide diversity of mutations in the $H B B$ genes makes mutation screening time-consuming and expensive. In the Southeast Asian population, the common beta-thalassemia mutations include c.-78 $\mathrm{A}>\mathrm{G}$, c. 2 T>A, c.52 A>T, c.84_85 insC, c.125_128 delTCTT, c.130 G>T, c.216_217 insA, and c.316-197 C>T [4]. 
A wide variety of methods for genotyping the $H B B$ gene have been developed using different detection techniques based on different principles [5], including allele-specific oligonucleotide hybridization (ASO) [6], amplification refractory mutation system (ARMS) [7], allele-specific PCR [8], reverse dot blot [9], restriction fragment length polymorphism (RFLP) [10], single base extension (SBE) $[11,12]$, and others [13-17]. These methods, however, are limited to the study of hotspot or known mutations. Additionally, single-strand conformation polymorphism (SSCP) $[18,19]$, denaturing gradient gel electrophoresis (DGGE) [20], temporal temperature gel electrophoresis (TTGE) [21], are efficient techniques to screen for unknown mutations. The advantage of these methods above is that it is inexpensive and suitable for large-scale research applications. However, its major disadvantage is lower detection rates. Recently, chemical cleavage of mismatch (CCM) [22] analysis has been reported to be a promising tool for mutation detection with advantages of accuracy, simplicity, and cost effectiveness, but it involves the use of toxic chemicals.

Enzymatic mismatch cleavage methods have been around for some time and include the use of T4 endonuclease VII [23], endonuclease V (Endo V) [24], mung bean nuclease [25], S1 nuclease [26], and CEL I nuclease [27-29]. There are growing numbers of publications describing the use of mismatch-specific endonuclease in the mutation discovery methods known as Tilling and Ecotilling [30-32].

In this study, we used the mismatch-specific endonuclease method to detect disease-causing mutations in the $H B B$ gene. The method was modified by amplifying the PCR products using three primers in the $H B B$ gene labeled at $5^{\prime}$ ends with fluorescent dyes. The results obtained using the mismatch-specific endonuclease method were compared with findings using denaturing high-performance liquid chromatography (DHPLC).

\section{Results \\ Detection of HBB Mutations by the Mismatch-specific Endonuclease Method}

Chemical cleavage of mismatch (CCM) is a highly specific and sensitive method to induce mismatch-cleavages [33]. However, the major disadvantage of CCM is the use of toxic chemicals during the process in the reactions or buffers, which could be avoided by using enzymatic mismatch cleavage. The celery enzyme is a member of a family of plant endonucleases that recognizes mismatches in heteroduplex DNA and cleaves both strands on the 3' side of the mismatch distortion [27]. To investigate the diagnostic value of this approach, the exons of $H B B$ genes were amplified by PCR using primers labeled at the 5 ' end with fluorescent dyes (Figure 1). We also employed a simple method to detect mutations in $H B B$ genes using the mismatch-specific endonuclease cleavage and separation of the PCR products by capillary electrophoresis. The approach is based on mismatch-specific selective reactions of mismatched DNA cleavage by endonuclease and separation of the PCR product fragments by capillary electrophoresis. This method is also adaptable to automated capillary electrophoresis which could increase its speed, sensitivity, and reproducibility, making it suitable for large-scale and high-throughput mutation screening.

We detected all the DNA variants of the $H B B$ gene including single base substitutions and deletions of TCTT. The different mutation sites and the expected sizes of PCR products cleaved by mismatch-specific endonuclease are described in Table 1. Samples of variant DNA fragments obtained with different base pairs were analyzed using capillary electrophoresis and the results are shown in Figure 2.

The PCR fragment amplified by the $\mathrm{B} 1$ and $\mathrm{B} 2$ primers was $337 \mathrm{bp}$; this fragment was cut into fragments of 107 bp and 230 bp by mismatch-specific endonuclease indicatingthe presence of c.-78 A>G mutation (Fig. 2A). Similar to the c.-78 $\mathrm{A}>\mathrm{G}$ variation, the common c.9 $\mathrm{C}>\mathrm{T}$ single nucleotide polymorphism (SNP) of the PCR fragment was cleaved to 193 bp and 144 bp (Fig. 2C).

Table I: Variation sites and the expected lengths of mismatch-specific endonuclease cleavage fragments for the human HBB gene

\begin{tabular}{|c|c|c|c|c|c|}
\hline \multirow[t]{2}{*}{ Variations Sites } & \multirow[t]{2}{*}{ Nucleotide Change } & \multirow[t]{2}{*}{ Amplicon } & \multirow[t]{2}{*}{ Mutation Type } & \multicolumn{2}{|c|}{ Expected Fragment Lengths (bp) } \\
\hline & & & & $\begin{array}{c}\text { Observation with FAM } \\
\text { labeling }\end{array}$ & Observation with HEX labeling \\
\hline c.-78 & $A>G$ & BIB2 (337 bp) & Regulatory & 107 & 230 \\
\hline c. 2 & $T>G$ & BIB2 (337 bp) & Misense & 186 & 151 \\
\hline c. 9 & $C>T$ & BIB2 (337 bp) & SNP & 193 & 144 \\
\hline c.52 & $A>T$ & BIB2 (337 bp) & Nonsense & 236 & 101 \\
\hline c. $125 \_128$ & delTCTT & B3B4 (287 bp) & Frame shift & 125 & 162 \\
\hline c.316-197 & $\mathrm{C}>\mathrm{T}$ & Y3Y4 (423 bp) & Splicing & 198 & 225 \\
\hline c.316-185 & $\mathrm{T}>\mathrm{C}$ & Y3Y4 (423 bp) & SNP & 210 & 213 \\
\hline
\end{tabular}





Figure I

Principles of the mismatch-specific endonuclease cleavage of the heteroduplex formation using primers labeled with two different fluorescent dyes.

The FAM- and HEX-labeled probes had the same sensitivity and specificity and could be used for double confirmation of the results. The formation of new cleavage products indicated the presence of variation, while their size provided some information about their location in the entire gene (Figure 3). The two variations could be also determined by the mismatch-specific endonuclease method as shown in Figure 2. The 107 bp, 230 bp, 186 bp, and 151 bp cutting by mismatch-specific endonuclease represented the presence of compound heterozygous variations (c.-78 A>G with c.2 T>A) (Fig. 2H). Similarly, the 193 bp, 144 bp, 236 bp, and 101 bp due to c.9 C>T polymorphism combined with the c.52 A $>$ T variation (Fig. 2I). The other DNA substitutions were identified by following this principle to predict the locations of the mutation sites. This technique could be the gold standard for the identification of healthy carriers, while for the diagnosis of affected patients direct sequencing probably remains the best approach, also considering the small size of HBB gene.

\section{Detection of HBB mutations by DHPLC}

DHPLC is a promising tool for mutations detection and gene quantification [34-36]. Previously, we developed a powerful and rapid PCR-DHPLC assay for detection of $H B B$ mutations [37]. However, DHPLC had better sensitivity and specificity in the analysis of heteroduplexes in PCR fragments shorter than $500 \mathrm{bp}$. In an attempt to increase sensitivity, we modified and optimized the PCR primers and DHPLC conditions for this study (Table 2), providing a significant advantage to this technique. The modified assay was used for identification of various genotypes of the $H B B$ gene (Figure 4) which were confirmed by direct sequencing. 


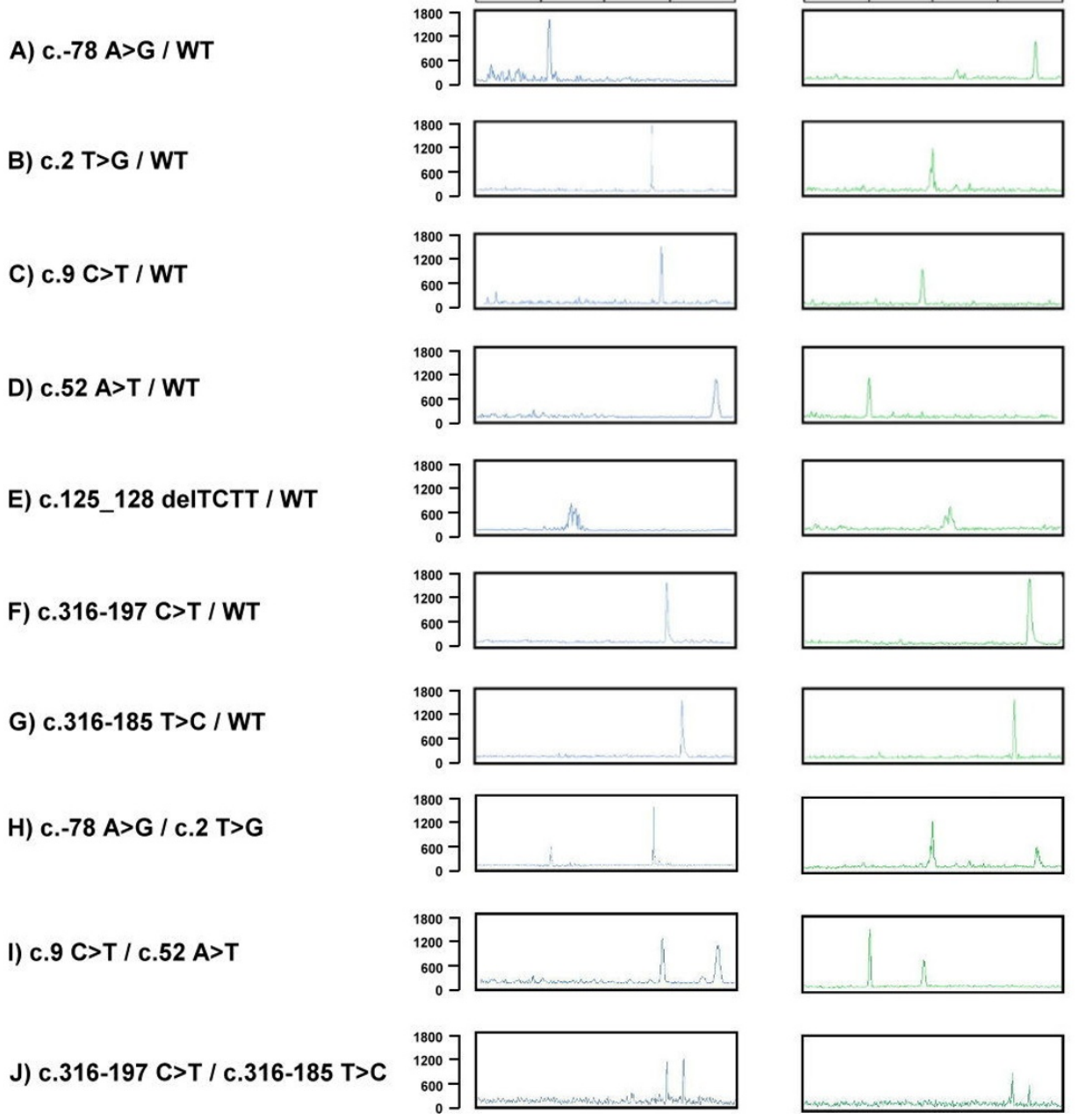

Figure 2

Capillary electrophoresis analysis of HBB genes for PCR products cleaved by mismatch-specific endonuclease fromA) an individual with a genotype of c.-78 A>G/WT, B) an individual with a genotype of c.2 T>G/WT, C) an individual with a genotype of c.9 C>T/WT, D) an individual with a genotype of c.52 A>T/WT, E) an individual with a genotype of c.125_I28 delTCTT/WT, F) an individual with a genotype of c.316-I97 C>T/WT, G) an individual with a genotype of c.3 I6-I85 T>C/ WT, H) an individual with a genotype of compound heterozygous mutation c.-78 A>G/c.2 T>G, I) an individual with a genotype of c. $9 \mathrm{C}>\mathrm{T} / \mathrm{c} .52 \mathrm{~A}>\mathrm{T}$, and $\mathrm{J})$ an individual with a genotype of c.3 I6-197 C>T/c.316-185 T>C.

$H B B$ genes could contain one or more mutations that could affect the results of DHPLC. This results in complex chromatography as shown in Figure 4, and failure to easily determine the genotype.

\section{Discussion}

Heteroduplex analysis based on DHPLC and mismatchspecific endonuclease with capillary electrophoresis both have the ability to detect unknown mutations. At present, direct sequencing is the gold standard and its use with multi-capillary electrophoresis, allows for high-throughput automation. Direct sequencing analysis is almost $100 \%$ sensitive for the detection of point mutations, small insertions, and deletions. The greatest advantage of DHPLC is its high sensitivity. This method shows small changes in peak chromatography according to differences in hydrophoretic mobility between heteroduplex and homoduplex DNA with high reproducibility. The main advantage of the mismatch-specific endonuclease cleavage method is that it can determine the locations of mutations with good sensitivity and without the use of toxic chemicals. Nonetheless, because it uses fluorescence technology, it is more expensive to run. In the present study, we were able to unambiguously identify all of the genotypes in $H B B$ variants by either of these methods with $100 \%$ sensitivity and specificity. 
70321 gtactgatgg tatggggcca agagatatat cttagaggga gggctgaggg tt tgaagtcc

70381 aactcctaag ccagtgccag aagagccaag gacaggtacg gctgtcatca cttagacctc

70441 accetgtgga gccacaccct agggttggcc atctactcc caggagcagg gagggcagga

70501 gccagggctg ggcataaaag tcagggcaga gccatctatt gcttacatt gcttctgaca c. $-78 \mathrm{~A}>\mathrm{G}$

70561 caactgtgtt cactagcaac ctcaaacaga caccatggtg cacctgactc ctgaggagaa

$$
\text { c. } 2 \mathrm{~T}>\mathrm{G} \quad \mathrm{c} .9 \mathrm{C}>\mathrm{T}
$$

70621 gtctgccgtt actgccetgt ggggcaaggt gaacgtggat gaagttggtg gtgaggecct c.52 A>T

70681 gggcaggttg gtatcaaggt tacaagacag gtttaaggag accaatagaa actgggcatg 70741 tggagacaga gaagactctt gggtttctga taggcactga ctctctctgc ctattggtct

70801 atttcccac cettaggctg ctggtggtct accettggac ccagaggtte tttgagtcct c.125_128 delTCTT

70861 ttggggatct gtccactcct gatgctgtta tgggcaaccc taaggtgaag gctcatggca 70921 agaaagtgct cggtgcctt agtgatggcc tggctcacct ggacaacctc aagggcacct

70981 ttgccacact gagtgagctg cactgtgaca agctgcacgt ggatcctgag aacttcaggg

71041 tgagtctatg ggacgcttga tgtttcttt cccettctt tctatggtta agttcatgtc

71101 ataggaaggg gataagtaac agggtacagt ttagaatggg aaacagacga atgattgcat

71161 cagtgtggaa gtctcaggat cgtttagt tctttatt gctgttcata acaattgtt

71221 tctttgtt aattctgct tettttt ttctctccg caattttac tattact

71281 aatgccttaa cattgtgtat aacaaagga aatatctctg agatacatta agtaact taa

71341 aaaaaact tacacagtct gcctagtaca ttactatt tg gaatatgt gtgct tatt

71401 gcatatcat aatctcccta ctttatt tc tttatttt aattgataca taatcattat

71461 acatattat gggttaagt gtaatgttt aatatgta cacatat ga ccaaatcagg

71521 gtaatttgc attgtaatt ttaaaaatg ctttcttctt ttaatact t t t tgttta

71581 tcttattct aatactttcc ctaatctct tcttcaggg caataatgat acaatgtatc

71641 atgcctctt gcaccattct aagaataac agtgataatt tctgggttaa ggcaatagca c.316-197 C>T

71701 atattctgc atataatat ttctgcatat aattgtaac tgatgtaaga ggtttcatat c. $316-185 \mathrm{~T}>\mathrm{C}$

71761 tgctaatagc agctacaatc cagctaccat tctgcttta ttttatggtt gggataggc

71821 tggattattc tgagtccaag ctaggccett ttgctaatca tgttcatacc tcttatct $\mathrm{c}$

71881 ctcccacagc tcctgggcaa cgtgctggtc tgtgtgctgg cccatcactt tggcaaagaa

71941 ttcacccac cagtgcaggc tgcctatcag aaatggtgg ctggtgtggc taatgccetg

\section{Figure 3}

Human beta-globin gene sequence (NG_000007), primer locations and the variation sites. The primers are labeled in boldface letters and blue font, the mutation sites are labeled in boldface letters and red font, and the polymorphism are marked in boldface letters and green font. The overlap sequence is labeled in pink font.

DHPLC, direct sequencing, and mismatch-specific endonuclease cleavage all require PCR amplification prior to screening. Thus, the major time factor is the machine run time. The DHPLC method can efficiently analyze one PCR product within $10 \mathrm{~min}$. While the mismatch-specific endonuclease method reactions used in this study required single runs on a single capillary electrophoresis machine, 96-capillary sequencers are available that can be used for mismatch-specific endonuclease cleavage and

Table 2: Primers used for DHPLC and mismatch-specific endonuclease cleavage analysis of the HBB gene

\begin{tabular}{|c|c|c|c|c|c|c|}
\hline Primer Name & Sequence (5'-3') & PCR Length (bp) & Anneal $\operatorname{Tm}\left({ }^{\circ} \mathrm{C}\right)$ & DHPLC Tm $\left({ }^{\circ} \mathrm{C}\right)$ & $\begin{array}{c}\text { DHPLC \% } \\
\text { Start/end }\end{array}$ & 5'-Label \\
\hline $\mathrm{BI}$ & gacaggtacggctgtcatca & 337 & 56 & 61 & $55-644.5 \mathrm{~min}$ & FAM \\
\hline B2 & gtctccacatgcccagtttc & & & & & HEX \\
\hline B3 & gaaactgggcatgtggagac & 287 & 56 & 61 & $55-644.5 \mathrm{~min}$ & FAM \\
\hline B4 & agcttgtcacagtgcagctc & & & & & HEX \\
\hline Y3 & gtgtacacatattgaccaaa & 423 & 56 & 56 & $56-654.5 \mathrm{~min}$ & FAM \\
\hline Y4 & agcacacagaccagcacgt & & & & & HEX \\
\hline
\end{tabular}


Amplicon B1B2 a)

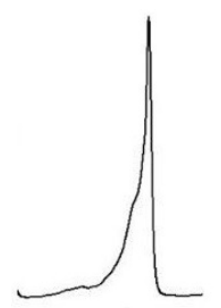

wt / wt



c. -78 A $>\mathrm{G} / \mathrm{WT}$ b) c)

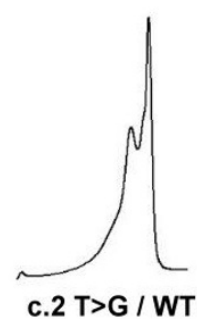

c) d)
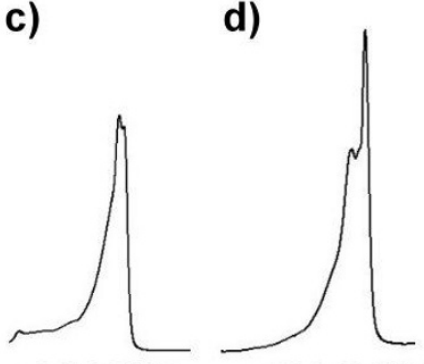

c.9 C > T / WT e)

f)

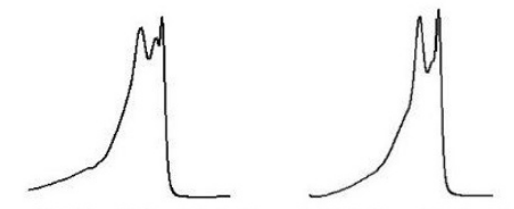

\section{Amplicon B3B4}

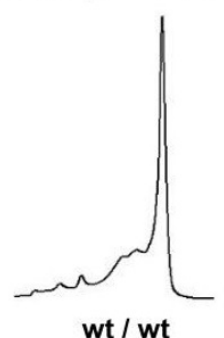

g)

Amplicon Y3Y4


j)

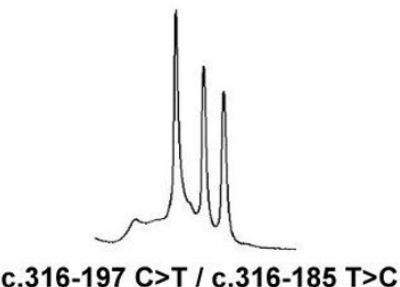

Figure 4

DHPLC chromatography analyses of HBB genes for PCR products. (amplicon BIB2 for a, b, c, d, e, f; B3B4 for $g$ and Y3Y4 for h, i, j). a) an individual with a genotype of c.-78 $A>G / W T, b)$ an individual with a genotype of c.2 T>G/WT, c) an individual with a genotype of c.9 C>T/WT, d) an individual with a genotype of c.52 A>T/WT, e) an individual with a compound heterozygous mutation c.-78 $\mathrm{A}>\mathrm{G} / \mathrm{c} .2 \mathrm{~T}>\mathrm{G}, \mathrm{f}$ ) an individual with a genotype of c.9 C>T/c.52 A>T, g) an individual with a genotype of c.125_I28 delTCTT/WT, h) an individual with a genotype of c.3 I6-197 C>T/WT, i) an individual with a genotype of c.3।6-I85 $\mathrm{T}>\mathrm{C} / \mathrm{W} T$, and j) an individual with a genotype of $\mathrm{c} .316-197 \mathrm{C}>\mathrm{T} / \mathrm{c} .316-185 \mathrm{~T}>\mathrm{C}$.

direct sequencing. The 96-capillary machine can process more samples per hour than a DHPLC machine [38].

We calculated the costs of the screening at approximately $\$ 6$ per patient for two different exons using DHPLC analysis and another $\$ 14$ for direct sequencing. The cost of the mismatch-specific endonuclease e cleavage mutation detection was calculated at about $\$ 9$ per exon, thus it cost approximately $\$ 18$ per patient for two exons.

In the case where a mutation and polymorphism occur in the same PCR amplicon, the variable polymorphism may affect the DHPLC profile and running conditions (Fig. 4); however, the two mutations could be determined by mismatch-specific endonuclease because the mismatch-specific endonuclease cleavage method can accurately identify the base variant and its location (Fig. 2). Nonetheless, the mismatch-specific endonuclease cleavage method is more time consuming and complicated because it requires FAM- and HEX-labeled primers. DHPLC is very simple and rapid and uses unlabeled primers. Data interpretations are easy with both the mismatchspecific endonuclease method and DHPLC. These two methodologies cannot detect large deletions or duplications in genotypes, however, unless multiplex PCR is designed for DHPLC or capillary electrophoresis [39-41]. 
On the other hand, Multiplex Ligation-dependent Probe Amplification (MLPA) [42] is more generally used to detect large deletions causing beta-thalassemia [43].

\section{Conclusion}

The mismatch-specific endonuclease method for beta-thalassemia mutations detection is merely as a model for other (large) disease genes for which large scale, highthroughput mutation scanning. This study demonstrated that the mismatch-specific endonuclease method was not only a comparatively faster procedure but was also significantly superior to DHPLC as a tool for gene mutation identification. The method is feasible for use in highthroughput systems due to an automated injection. This method is thus well suited for screening and may also reduce costs.

\section{Methods \\ DNA Extraction}

DNA samples were obtained from a total of 50 subjects, including 20 carriers, 20 patients, and 10 normal individuals at National Taiwan University Hospital. Genomic DNA was collected from peripheral whole blood using the Chemagic DNA Blood Kit (Chemagen) according to the manufacturer's instructions. The different genotypes of the DNA samples used in the mismatch-specific endonuclease study are shown in Table 1.

\section{Polymerase Chain Reaction}

PCR primers and conditions for each exon to amplify the $H B B$ gene were modified according to previously reported methods [37] and are described in Table 2. The PCR techniques for the provided DNA fragments were performed in a total volume of $25 \mu \mathrm{l}$ containing $50 \mathrm{ng}$ of genomic DNA; $0.12 \mu \mathrm{M}$ of each primer; $100 \mu \mathrm{M}$ dNTPs; 0.5 units of AmpliTaq Gold enzyme (Applied Biosystems); $2.5 \mu \mathrm{l}$ of GeneAmp $10 \times$ buffer II $(10 \mathrm{mmol} / \mathrm{L}$ Tris-HCl, pH 8.3, 50 $\mathrm{mmol} / \mathrm{L} \mathrm{KCl}$ ), in $2 \mathrm{mmol} / \mathrm{L} \mathrm{MgCl} 2$ as provided by the manufacturer. Amplification was performed in a multiblock system (MBS) thermocycler (ThermoHybaid). PCR amplification began with denaturation at $95^{\circ} \mathrm{C}$ for $5 \mathrm{~min}$, followed by 35 cycles of denaturation at $94^{\circ} \mathrm{C}$ for $30 \mathrm{~s}$, annealing at $56^{\circ} \mathrm{C}$ for $30 \mathrm{~s}$, extension at $72^{\circ} \mathrm{C}$ for $45 \mathrm{~s}$, and a final extension step at $72^{\circ} \mathrm{C}$ for $10 \mathrm{~min}$.

\section{DHPLC Analysis}

Mutations screening was performed using the Transgenomic Wave Nucleic Acid Fragment Analysis System (Transgenomic Inc.) with a $\mathrm{C}_{18}$ reversed-phase column, which was based on 2- $\mu \mathrm{m}$ nonporous poly (styrene/divinylbenzene) particles (DNASep column, Transgenomic Inc.). PCR products were analyzed in a linear acetonitrile gradient with triethylammonium acetate as the mobile phase, using buffer A (0.1 M TEAA) and buffer B (0.1 M TEAA with $25 \%$ acetonitrile) (WAVE Optimized, Transge- nomic Inc.). Heteroduplex analyses were performed according to the manufacturer's protocol and previous studies $[37,44,45]$.

\section{Purification of PCR Products}

In the mismatch-specific endonuclease process, the Microcon YM-100 system (Millipore Corp.) was used to remove excess primers and unincorporated dNTPs to purify the PCR products.

\section{Mismatch-specific Endonuclease Method}

After PCR amplification and purification, the PCR product was digested by mismatch-specific endonuclease using the SURVEYOR kit with the fluorescent capillary electrophoresis system (Transgenomic). The PCR products were assayed in a total volume of $60 \mu \mathrm{l}$ containing $15 \mu \mathrm{l}$ of PCR product, $6 \mu \mathrm{l}$ of $10 \times$ Surveyor Nuclease reaction buffer, 1 $\mu$ l of Surveyor Nuclease Enhancer W, and $1 \mu$ l of Surveyor Nuclease W (Surveyor) as provided by the manufacturer. Mismatch-specific endonuclease digestion was performed at $42^{\circ} \mathrm{C}$ for $20 \mathrm{~min}$, followed by adding $6 \mu \mathrm{l}$ of stop solution as provided by the manufacturer.

\section{Capillary Electrophoresis}

The final mismatch-specific endonuclease digestion product $(2 \mu \mathrm{l})$ was diluted with $10 \mu \mathrm{l}$ of Hi-Di formamide (Applied Biosystems) and $0.25 \mu \mathrm{l}$ of ROX size standard (Applied Biosystems). Samples were heated at $95^{\circ} \mathrm{C}$ for 5 min and cooled on ice for $5 \mathrm{~min}$. Each mixture was injected into the ABI PRISM 310 Genetic Analyzer (Applied Biosystems) and was separated across a capillary containing POP-4 polymer (Applied Biosystems). The results were analyzed using GeneScan application software (Applied Biosystems) according to the manufacturer's protocol [46].

\section{Sequencing}

For sequencing, the PCR products were purified by solidphase extraction and bi-directionally sequenced with the Applied Biosystems Taq DyeDeoxy terminator cycle sequencing kit (Applied Biosystems) according to the manufacturer's instructions. Sequencing reactions were separated on a PE Biosystems 373A/3100 sequencer.

\section{Authors' contributions}

$\mathrm{C}-\mathrm{CH}$ and $\mathrm{Y}-\mathrm{NS}$ performed the molecular genetics studies and drafted the manuscript. C-YL, Y-HC and C-HC participated in the molecular genetics studies. W-FC and $\mathrm{C}-\mathrm{AC}$ performed the clinical characterization of the patients. W-LL participated in designing the study. C-NL conceived of the study, participated in its design and coordination, and helped draft the manuscript. All authors read and approved the final manuscript. 


\section{Acknowledgements}

We are very grateful to all of the patients who participated in this research. The authors acknowledge Dr. Fon-Jou Hsieh for his expert assistance. We thank the National Science Council of Taiwan (NSC 93-23।4-B-002-I66; NSC 94-23 I4-B-002-048) for financial support.

\section{References}

I. Tuzmen S, Schechter AN: Genetic diseases of hemoglobin: diagnostic methods for elucidating beta-thalassemia mutations. Blood Rev 2001, I5(I): 19-29.

2. Huisman TH, Carver MF: The beta- and delta-thalassemia repository (Ninth Edition; Part I). Hemoglobin 1998, 22(2): 169-195.

3. Hardison RC, Chui DH, Giardine B, Riemer C, Patrinos GP, Anagnou $\mathrm{N}$, Miller $\mathrm{W}$, Wajcman $\mathrm{H}$ : HbVar: A relational database of human hemoglobin variants and thalassemia mutations at the globin gene server. Hum Mutat 2002, I9(3):225-233.

4. Bhardwaj U, Zhang YH, Lorey F, McCabe LL, McCabe ER: Molecular genetic confirmatory testing from newborn screening samples for the common African-American, Asian Indian, Southeast Asian, and Chinese beta-thalassemia mutations. Am J Hematol 2005, 78(4):249-255.

5. Patrinos GP, Kollia P, Papadakis MN: Molecular diagnosis of inherited disorders: lessons from hemoglobinopathies. Hum Mutat 2005, 26(5):399-4I2.

6. Baig SM, Azhar A, Hassan H, Baig JM, Kiyani A, Hameed U, Rabbi F, Bokhari H, Aslam M, Ud Din MA, et al.: Spectrum of beta-thalassemia mutations in various regions of Punjab and Islamabad, Pakistan: establishment of prenatal diagnosis. Haematologica 2006, 9 I(3):ELT02.

7. Old JM, Varawalla NY, Weatherall DJ: Rapid detection and prenatal diagnosis of beta-thalassaemia: studies in Indian and Cypriot populations in the UK. Lancet 1990, 336(87 I 9):834-837.

8. Hattori $Y$ : Thalassemia mutations and their clinical aspects in Japan. Int J Hematol 2002, 76(Suppl 2):90-92.

9. Maggio A, Giambona A, Cai SP, Wall J, Kan YW, Chehab FF: Rapid and simultaneous typing of hemoglobin $S$, hemoglobin $C$, and seven Mediterranean beta-thalassemia mutations by covalent reverse dot-blot analysis: application to prenatal diagnosis in Sicily. Blood 1993, 8 I (I):239-242.

10. Ward MA, Olivieri NF, Ng J, Roder JC: Detection of beta-thalassemia using an artificial-restriction fragment length polymorphism generated by the polymerase chain reaction. Nucleic Acids Res 1991, 19(4):959.

II. Brazill SA, Kuhr WG: A single base extension technique for the analysis of known mutations utilizing capillary gel electrophoreisis with electrochemical detection. Anal Chem 2002, 74( 14):342I-3428.

12. Liao HK, Su YN, Kao HY, Hung CC, Wang HT, Chen YJ: Parallel minisequencing followed by multiplex matrix-assisted laser desorption/ionization mass spectrometry assay for beta-thalassemia mutations. I Hum Genet 2005, 50(3): I 39-I50.

13. Graham D, Mallinder BJ, Whitcombe D, Watson ND, Smith WE: Simple multiplex genotyping by surface-enhanced resonance Raman scattering. Anal Chem 2002, 74(5): I069-1074.

14. Moreno I, Bolufer P, Perez ML, Barragan E, Sanz MA: Rapid detection of the major Mediterranean beta-thalassaemia mutations by real-time polymerase chain reaction using fluorophore-labelled hybridization probes. Br J Haematol 2002, I I 9(2):554-557.

15. Gelfi C, Vigano A, Carta P, Manchia P, Cossu GF, Righetti PG: Screening for the beta-39 mutation in thalassemia by capillary electrophoresis in free solution in strongly acidic, isoelectric buffers. Electrophoresis 2000, 2 I (4):780-784.

16. Fortina P, Dotti G, Conant R, Monokian G, Parrella T, Hitchcock W, Rappaport E, Schwartz E, Surrey S: Detection of the most common mutations causing beta-thalassemia in Mediterraneans using a multiplex amplification refractory mutation system (MARMS). PCR Methods Appl 1992, 2(2): I63-166.

17. Ross PL, Lee K, Belgrader P: Discrimination of single-nucleotide polymorphisms in human DNA using peptide nucleic acid probes detected by MALDI-TOF mass spectrometry. Anal Chem 1997, 69(20):4197-4202.

18. Takahashi-Fujii A, Ishino Y, Kato I, Fukumaki Y: Rapid and practical detection of beta-globin mutations causing beta-thalassemia by fluorescence-based PCR-single-stranded conformation polymorphism analysis. Mol Cell Probes 1994, 8(5):385-393.

19. Kourkine IV, Hestekin CN, Buchholz BA, Barron AE: High-throughput, high-sensitivity genetic mutation detection by tandem single-strand conformation polymorphism/heteroduplex analysis capillary array electrophoresis. Anal Chem 2002, 74(I I):2565-2572.

20. Losekoot M, Fodde R, Harteveld CL, van Heeren H, Giordano PC, Bernini LF: Denaturing gradient gel electrophoresis and direct sequencing of PCR amplified genomic DNA: a rapid and reliable diagnostic approach to beta thalassaemia. $\mathrm{Br} J$ Haematol 1990, 76(2):269-274.

21. Shaji RV, Edison ES, Poonkuzhali B, Srivastava A, Chandy M: Rapid detection of beta-globin gene mutations and polymorphisms by temporal temperature gradient gel electrophoresis. Clin Chem 2003, 49(5):777-78।.

22. Dianzani I, Camaschella C, Saglio G, Forrest SM, Ramus S, Cotton RG: Simultaneous screening for beta-thalassemia mutations by chemical cleavage of mismatch. Genomics I99I, I I (I):48-53.

23. Youil R, Toner T], Bull E, Bailey AL, Earl CD, Dietz HC, Montgomery RA: Enzymatic mutation detection (EMD) of novel mutations (R565X and RI 523X) in the FBN I gene of patients with Marfan syndrome using T4 endonuclease VII. Hum Mutat 2000, I 6(I):92-93

24. Huang J, Lu J, Barany F, Cao W: Mutational analysis of endonuclease V from Thermotoga maritima. Biochemistry 2002, 4 I (26):8342-8350.

25. Dowton $M$, Austin AD: Direct sequencing of double-stranded PCR products without intermediate fragment purification; digestion with mung bean nuclease. Nucleic Acids Res 1993, 2 I (I5):3599-3600.

26. Dickson LA, Pihlajaniemi T, Deak S, Pope FM, Nicholls A, Prockop DJ, Myers JC: Nuclease SI mapping of a homozygous mutation in the carboxyl-propeptide-coding region of the pro alpha 2 (I) collagen gene in a patient with osteogenesis imperfecta. ProC Natl Acad Sci USA 1984, 8 I ( I 4):4524-4528.

27. Yang B, Wen X, Kodali NS, Oleykowski CA, Miller CG, Kulinski J, Besack D, Yeung JA, Kowalski D, Yeung AT: Purification, cloning, and characterization of the CEL I nuclease. Biochemistry 2000, 39(I3):3533-354I

28. Qiu P, Shandilya H, D'Alessio JM, O'Connor K, Durocher J, Gerard GF: Mutation detection using Surveyor nuclease. Biotechniques 2004, 36(4):702-707.

29. Oleykowski CA, Bronson Mullins CR, Godwin AK, Yeung AT: Mutation detection using a novel plant endonuclease. Nucleic Acids Res 1998, 26(20):4597-4602.

30. Till BJ, Zerr T, Bowers E, Greene EA, Comai L, Henikoff S: Highthroughput discovery of rare human nucleotide polymorphisms by Ecotilling. Nucleic Acids Res 2006, 34(I3):e99.

31. Comai L, Henikoff S: TILLING: practical single-nucleotide mutation discovery. Plant J 2006, 45(4):684-694.

32. Stemple DL: TILLING-a high-throughput harvest for functional genomics. Nat Rev Genet 2004, 5(2): |45-I50.

33. Ellis TP, Humphrey KE, Smith MJ, Cotton RG: Chemical cleavage of mismatch: a new look at an established method. Hum Mutat 1998, I I(5):345-353.

34. Kosaki K, Udaka T, Okuyama T: DHPLC in clinical molecular diagnostic services. Mol Genet Metab 2005, 86(I-2): I I7-I 23.

35. Hung CC, Lee CN, Chen CP, Jong YJ, Chen CA, Cheng WF, Lin WL, Su YN: Quantification of relative gene dosage by single-base extension and high-performance liquid chromatography: application to the SMNI/SMN2 gene. Anal Chem 2005, 77(2I):6960-6968.

36. Weber J, Barbier V, Pages-Berhouet S, Caux-Moncoutier V, StoppaLyonnet D, Viovy JL: A high-throughput mutation detection method based on heteroduplex analysis using graft copolymer matrixes: application to Brcal and Brca2 analysis. Anal Chem 2004, 76( I 6):4839-4848.

37. Su YN, Lee CN, Hung CC, Chen CA, Cheng WF, Tsao PN, Yu CL, Hsieh FJ: Rapid detection of beta-globin gene (HBB) mutations coupling heteroduplex and primer-extension analysis by DHPLC. Hum Mutat 2003, 22(4):326-336.

38. Pang $H$, Pavski V, Yeung ES: DNA sequencing using 96-capillary array electrophoresis. J Biochem Biophys Methods 1999, 4I(23): $121-132$ 
39. Hung CC, Chen CP, Lin SP, Chien SC, Lee CN, Cheng WF, Hsieh WS, Liu MS, Su YN, Lin WL: Quantitative assay of deletion or duplication genotype by capillary electrophoresis system: Application in Prader-Willi syndrome and Duchenne muscular dystrophy. Clin Chem 2006, 52(I 2):2203-22I0.

40. Hung CC, Su YN, Lin CY, Yang CC, Lee WT, Chien SC, Lin WL, Lee $\mathrm{CN}$ : Denaturing HPLC coupled with multiplex PCR for rapid detection of large deletions in Duchenne muscular dystrophy carriers. Clin Chem 2005, 5 I (7): I 252- I256.

4I. Su YN, Hung CC, Li H, Lee CN, Cheng WF, Tsao PN, Chang MC, Yu CL, Hsieh WS, Lin WL, et al.: Quantitative analysis of SMNI and SMN2 genes based on DHPLC: a highly efficient and reliable carrier-screening test. Hum Mutat 2005, 25(5):460-467.

42. Schouten JP, McElgunn CJ, Waaijer R, Zwijnenburg D, Diepvens F, Pals G: Relative quantification of $\mathbf{4 0}$ nucleic acid sequences by multiplex ligation-dependent probe amplification. Nucleic Acids Res 2002, 30(12):e57.

43. Harteveld CL, Voskamp A, Phylipsen M, Akkermans N, den Dunnen JT, White SJ, Giordano PC: Nine unknown rearrangements in $16 \mathrm{pI} 3.3$ and IIpI5.4 causing alpha- and beta-thalassaemia characterised by high resolution multiplex ligation-dependent probe amplification. J Med Genet 2005, 42(I2):922-93I.

44. Xiao W, Oefner PJ: Denaturing high-performance liquid chromatography: A review. Hum Mutat 200I, I7(6):439-474.

45. Hung CC, Su YN, Chien SC, Liou HH, Chen CC, Chen PC, Hsieh CJ, Chen CP, Lee WT, Lin WL, et al.: Molecular and clinical analyses of 84 patients with tuberous sclerosis complex. BMC Med Genet 2006, 7:72.

46. Butler JM, Buel E, Crivellente F, McCord BR: Forensic DNA typing by capillary electrophoresis using the ABI Prism 310 and 3100 genetic analyzers for STR analysis. Electrophoresis 2004, 25(I0-II):|397-I4|2.

Publish with Bio Med Central and every scientist can read your work free of charge

"BioMed Central will be the most significant development for disseminating the results of biomedical research in our lifetime. "

Sir Paul Nurse, Cancer Research UK

Your research papers will be:

- available free of charge to the entire biomedical community

- peer reviewed and published immediately upon acceptance

- cited in PubMed and archived on PubMed Central

- yours - you keep the copyright
BioMedcentral 